\title{
Chlorophyllin Treatment Against the Snail Lymnaea acuminata: A new tool in Fasciolosis Control
}

\author{
Kavita Singh', D.K. Singh ${ }^{2}$, Vinay Kumar Singh ${ }^{3 *}$
}

\section{Kavita Singh, DK Singh and Vinay Kumar Singh*}

Malacology Laboratory, Department of Zoology, D.D.U. Gorakhpur University, Gorakhpur, Uttar Pradesh, INDIA.

Correspondence

Vinay Kumar Singh, Malacology Laboratory, Department of Zoology, D.D.U. Gorakhpur University, Gorakhpur, Uttar Pradesh, Pin: 273 009, INDIA.

Tel.: (O) +91-551-2202187;

(M) $+91-9415855488$

E-mail: vinaygkpuniv@gmail.com

History

- Submission Date: 23-02-2017.

- Review completed: 22-03-2017;

- Accepted Date: 28-03-2017

DOI : 10.5530/pj.2017.5.94

Article Available online

http://www.phcogj.com/v9/i5

\section{Copyright}

(C) 2017 Phcog.Net. This is an openaccess article distributed under the terms of the Creative Commons Attribution 4.0 International license.

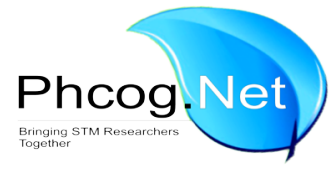

\begin{abstract}
Objective: To observe the toxicity of chlorophyllin against Lymnaea acuminata to control fasciolosis caused by liver fluke fasciola gigantica, very prominent in eastern region of Uttar Pradesh. Materials and Methods: Ten snails Lymnaea acuminata were placed in a glass aquarium containing $3 \mathrm{~L}$ of dechlorinated tap water. These snails were treated with different concentrations of chlorophyllin. Chlorophyll was extracted from spinach with the help of macerated leaves and kept for $2 \mathrm{~h}$ in $100 \%$ ethanol at $55^{\circ} \mathrm{C}$. Results: The results of the experiment showed that the photodynamically active chlorophyllin, at low concentration was able to kill the snails under exposure of solar radiation in summer season instead of winter season. In winter, extracted chlorophyllin toxicity against $L$. acuminata in sunlight $\left(96 \mathrm{~h} \mathrm{LC}_{50}\right.$ $91.82 \mathrm{mg} \mathrm{L}^{-1}$ ) /laboratory condition (96 h LC $\mathrm{LC}_{50} 921.93 \mathrm{mg} \mathrm{L}^{-1}$ ) was less than pure chlorophyllin in sunlight (96 h LC $12.05 \mathrm{mg} \mathrm{L}^{-1}$ ) /laboratory condition (96 $\mathrm{h} \mathrm{LC}_{50} 19.22 \mathrm{mg} \mathrm{L}^{-1}$ ), respectively. In summer, pure chlorophyllin was more toxic in sunlight (96 $\mathrm{h} \mathrm{LC}_{50} 3.90 \mathrm{mg} \mathrm{L}^{-1}$ ) than laboratory condition (96 h LC $50.18 \mathrm{mg} \mathrm{L}^{-1}$ ). Pure chlorophyllin is more than five times toxic than synthetic molluscicides. Treatment of chlorophyllin caused no toxic effect against the fish (Colisa fasciatus). The result presented in this paper is found very beneficial and ecologically safe, as a photodynamic substance chlorophyllin, which found in every green plant. Conclusion: Phytotherapy of snails by photodynamic water soluble chlorophyllin to control fasciolosis can be used as potent molluscicides with low cost and easily biodegradable.

Key words: Fasciolosis, Lymnaea acuminata, Fasciola gigantica, Plant molluscicide, Chlorophyllin, Photodynamic reaction.
\end{abstract}

\section{INTRODUCTION}

Fasciolosis is a zoonotic disease and third most prevalent disease in the world. ${ }^{1-3}$ Human fasciolosis and it outbreaks in the last two decades have changed the status of fasciolosis from a zoonosis to an emerging health problem in tropics. ${ }^{4,5}$ Fasciola gigantica is the causative agent of fasciolosis in eastern Uttar Pradesh, India. ${ }^{6,7}$ Snails are the important links in transmission of fasciolosis. The snail Lymnaea acuminata is the intermediate host of F. gigantica. ${ }^{89}$ An obvious preventive method to reduce the incidence of fasciolosis is to control the population of carrier snail. Indiscriminate use of synthetic molluscicides such as Carbamates and organophosphates has created several environmental hazards. ${ }^{10}$ So that, plant molluscicides are advocated as they are easily biodegradable, cheap and easier to handle by native users. ${ }^{11,12}$

Chlorophyll is found in all green plants. Chlorophyll product chlorophyllin is extremely toxic against mosquito larvae in sunlight. ${ }^{13,14}$ Recently, Singh and Singh $^{7}$ noted the cercaricidal activity of chlorophyllin against Fasciola gigantica larvae. The present study reports the molluscicidal activity of chlorophyllin against host snail L. acuminata.

\section{MATERIALS AND METHODS}

\section{Pure Compound}

Chlorophyllin is purchased from Sigma Chemical Co. USA.

\section{Experimental Animal}

Adult L. acuminata of average size $(2.25 \pm 0.30$ in length) were collected locally from ponds, lakes and low-lying submerged fields of the district Gorakhpur, UP, India. Gorakhpur lies between latitude $26^{\circ} 46^{\prime} \mathrm{N}$ and longitude $83^{\circ} 22^{\prime} \mathrm{E}$ at an altitude of 95 meter above the sea level. The collected snails were kept in glass aquarium containing de-chlorinated tap water for $72 \mathrm{~h}$ for acclimatization. The animals were kept in de-chlorinated tap water at room temperature $\left(22-25^{\circ} \mathrm{C}\right)$. The $\mathrm{pH}$, dissolved oxygen, free carbon dioxide and bicarbonate alkalinity were 7.1-7.3; 6.5-7.3 mg L $\mathrm{mg}^{-1}$; 5.2-6.3 $\mathrm{mg} \mathrm{L}^{-1}$ and 102-105 $\mathrm{mg} \mathrm{L}^{-1}$, respectively. Water was changed once every $24 \mathrm{~h}$ and dead animals were removed to prevent the water from being contaminated by decaying tissue.

\section{Preparation of Chlorophyllin}

Chlorophyllin was prepared by the method of Wohllebe et al. ${ }^{14}$ Chlorophyll was extracted from spinach with the help of macerated leaves for $2 \mathrm{~h}$ in $100 \%$ 
ethanol at $55^{\circ} \mathrm{C}$. To avoid transformation of chlorophyll into pheophytin by the acidic content of the cell vacuoles $1.0 \mathrm{mg} \mathrm{CaCO} / \mathrm{g}$ leaves were added as a buffer. The extract was subsequently filtered and equal volume of petroleum benzene was added. After shaking the mixture the chlorophyll moved into the lipophillic benzene phase. The two phases were separated in separatory funnel and about $1 \mathrm{ml}$ methanolic $\mathrm{KOH}$ was added to $50 \mathrm{ml}$ of the benzene phase. The chlorophyll came into contact with the methanolic $\mathrm{KOH}$ and was transformed into water-soluble chlorophyllin (this process occurs due to the breakage of the ester bond between the chlorophyllin and the phytol tail by saponification).

\section{Toxicity-Determination}

Toxicity experiments were done according to the method of Singh and Agarwal. ${ }^{15}$ Ten experimental snails were placed in a glass aquarium containing $3 \mathrm{~L}$ of de-chlorinated tap water. The experiment was setup with two groups and in the I group the control 1 snails were kept in laboratory condition (winter/summer) after $4 \mathrm{~h}$ of dark incubation for $96 \mathrm{~h}$ with no chlorophyllin, and control 2 put into the sunlight condition (winter/summer) and all the condition was same as in control 1. Further in the II group the treatment 1 were kept in laboratory condition (mercury light intensity $150 \mathrm{~W} / \mathrm{m}^{2}$, winter/summer) and treatment 2 in sunlight condition (light intensity $900 \mathrm{~W} / \mathrm{m}^{2}$ in winter and $1200 \mathrm{~W} / \mathrm{m}^{2}$ in summer). Light intensity was measure with the help of digital lux meter (Mextech LX-1010B) in flux. Thereafter, it has been converted in irradiance $\mathrm{W} / \mathrm{m}^{2}$. Snail mortality was recorded at every $24 \mathrm{~h}$ upto $96 \mathrm{~h}$. Each treatment was replicated six times. Dead animals were removed immediately from the aquarium to avoid any contamination of the water. Snail mortality was confirmed by the contraction of the body within the shell and absence of any response to a needle probe. Toxicity determinations were also studied against non-target animal fish Colisa fasciatus. A group III of ten fishes were taken in a $6 \mathrm{~L}$ dechlorinated tap water and all the conditions were same as in group I and group II. The fishes were treated with $24 \mathrm{~h}$ Lethal Concentration ${ }_{90}\left(\mathrm{LC}_{90}\right.$ against L. acuminata) for $96 \mathrm{~h}$ in the same experimental condition as in snail treatment.

The slope value of the probit line was also estimated. This program ran chi-square tests for goodness of fit of the data to the probit model. If the model fits, the calculated value of chi-square is less than the chi-square table value for appropriate degree of freedom. If the model does not fit, the $\mathrm{LC}_{50}$ value for the particular population may not be reliably estimated and is adjusted with the heterogeneity factor as correction factor when the value of Pearson's chi-square statistics is significant at $\mathrm{P}=0.05$. The index of significance for potency estimation (g-value) was used to calculate $95 \%$ confidence intervals for potency (relative potency is equivalent to tolerance ratio). Parallelism of the probit regression lines implies a constant relative potency at all levels of response. POLO-PC (LeOra software) of Robertson et $a l^{16}$ was used to test equality and parallelism of the slope of the probit lines was calculated by using the probit analysis programme. The regression co-efficient was determined between exposure time and different values of $\mathrm{LC}_{50}$ by the method of Sokal and Rohlf ${ }^{17}$.

\section{RESULTS}

The toxicity of chlorophyllin against L. acuminata was concentration and time- dependent. In winter, toxicity of extracted and pure chlorophyllin in laboratory condition ( $96 \mathrm{~h} \mathrm{LC}_{50}$ Extracted- $921.93 \mathrm{mg} \mathrm{L}^{-1}$, Pure- 19.22 $\left.\mathrm{mg} \mathrm{L}^{-1}\right)$ was lower than the sunlight $\left(96 \mathrm{~h} \mathrm{LC}_{50}\right.$ extracted- $91.82 \mathrm{mg} \mathrm{L}^{-1}$, Pure- $\left.12.05 \mathrm{mg} \mathrm{L}^{-1}\right)$. Whereas, in summer toxicity of extracted and pure chlorophyllin in laboratory condition $\left(96 \mathrm{~h} \mathrm{LC}_{50}\right.$ Extracted- $257.11 \mathrm{mg} \mathrm{L}^{-1}$, Pure- $7.18 \mathrm{mg} \mathrm{L}^{-1}$ ) was lower than the sunlight $\left(96 \mathrm{~h} \mathrm{LC}_{50}\right.$ extracted$24.95 \mathrm{mg} \mathrm{L}^{-1}$, Pure- $3.90 \mathrm{mg} \mathrm{L}^{-1}$ ) (Table 1 and 2).

Toxicity of extracted chlorophyllin against L. acuminata was 1.75 to 3.68 times higher in summer than winter. Whereas, pure chlorophyllin toxicity was 2.67 to 4.84 times higher in summer than winter. The toxicity of pure chlorophyllin in laboratory condition $\left(96 \mathrm{~h} \mathrm{LC}_{50} 7.18 \mathrm{mg} \mathrm{L}^{-1}\right)$ was less effective than sunlight ( $96 \mathrm{~h} \mathrm{LC}_{50} 3.90 \mathrm{mg} \mathrm{L}^{-1}$ ) (Table 1 and 2). No mortality in snails was noted in group III control 1 and contr.ol 2 as well as fish treated with $24 \mathrm{~h} \mathrm{LC}_{90}$ against L. acuminata. No mortality in fish population may be either due to rapid detoxification of chlorophyllin in fish body or the concentration range used for the snails is safe against fish. The slope values were steep and separate estimations of $\mathrm{LC}_{50}$, based on each of the six replicates, were found within the $95 \%$ confidence limits of $\mathrm{LC}_{50}$. The t-ratio values were greater than 1.96 indicating a significant regression of each dose response line. The heterogeneity factor was less than 1.0, demonstrating the log-dose-probit lines are within the 95\% confidence limits and thus the model fitted our data. Value of $g$ less than 0.5 indicated that mean was within the limit at all probability levels of 90,95 and $95 \%$.

\section{DISCUSSION}

The results of the present study indicate that the chlorophyllin extracted from spinach is a potent source of plant molluscicides. Toxicity of chlorophyllin is time and concentration dependent, as evident from negative

\begin{tabular}{|c|c|c|c|c|c|c|c|c|}
\hline \multirow[t]{2}{*}{$\begin{array}{l}\text { Exposure } \\
\text { time }\end{array}$} & \multirow[t]{2}{*}{ Treatment } & \multicolumn{3}{|c|}{$\begin{array}{c}\text { Winter } \\
\text { LC }_{50} \\
\text { (LCL-UCL) }\end{array}$} & \multicolumn{4}{|c|}{$\begin{array}{c}\text { Summer } \\
\text { LC }_{50} \\
\text { (LCL-UCL) }\end{array}$} \\
\hline & & $\begin{array}{l}\text { Dec } \\
19^{\circ} \mathrm{C} \\
\end{array}$ & $\begin{array}{l}\text { Jan } \\
16^{\circ} \mathrm{C} \\
\end{array}$ & $\begin{array}{l}\text { Feb } \\
21^{\circ} \mathrm{C} \\
\end{array}$ & $\begin{array}{l}\text { March } \\
29^{\circ} \mathrm{C} \\
\end{array}$ & $\begin{array}{l}\text { Apr } \\
39^{\circ} \mathrm{C} \\
\end{array}$ & $\begin{array}{l}\text { May } \\
32^{\circ} \mathrm{C} \\
\end{array}$ & $\begin{array}{l}\text { Jun } \\
39^{\circ} \mathrm{C}\end{array}$ \\
\hline \multirow[t]{2}{*}{$24 \mathrm{~h}$} & Ext Chl & \multicolumn{3}{|c|}{$\begin{array}{c}958.96 \\
(951.76-969.07)\end{array}$} & \multicolumn{4}{|c|}{$\begin{array}{c}545.59 \\
(465.99-743.74)\end{array}$} \\
\hline & Pure Chl & $\begin{array}{r}62 \\
(46.45\end{array}$ & $\begin{array}{l}26 \\
13.65\end{array}$ & & & $\begin{array}{r}12 \\
(11.06\end{array}$ & $\begin{array}{l}34 \\
17.08)\end{array}$ & \\
\hline \multirow[t]{2}{*}{$48 \mathrm{~h}$} & Ext Chl & \multicolumn{3}{|c|}{$(937.44-951.37)$} & \multicolumn{4}{|c|}{$(373.85-504.13)$} \\
\hline & Pure Chl & $\begin{array}{r}40 \\
(30.10\end{array}$ & $\begin{array}{l}11 \\
70.84)\end{array}$ & & \multicolumn{4}{|c|}{$\begin{array}{c}9.49 \\
(8.51-11.04)\end{array}$} \\
\hline \multirow[t]{2}{*}{$72 \mathrm{~h}$} & Ext Chl & $\begin{array}{r}93 \\
(926.67\end{array}$ & $\begin{array}{l}42 \\
939.79\end{array}$ & & \multicolumn{4}{|c|}{$\begin{array}{c}319.51 \\
(284.81-355.74)\end{array}$} \\
\hline & Pure Chl & $\begin{array}{r}29 \\
(21.69\end{array}$ & $\begin{array}{l}66 \\
44.43)\end{array}$ & & & $\begin{array}{r}8 \\
(7.42\end{array}$ & $\begin{array}{l}6 \\
9.31)\end{array}$ & \\
\hline \multirow[t]{2}{*}{$96 \mathrm{~h}$} & Ext Chl & \multicolumn{3}{|c|}{921.93} & \multicolumn{4}{|c|}{$\begin{array}{c}257.11 \\
(223.08-285.07)\end{array}$} \\
\hline & Pure Chl & \multicolumn{3}{|c|}{19.22} & \multicolumn{4}{|c|}{7.18} \\
\hline
\end{tabular}

Each experiment was replicated six times. Toxicity measured at intervals of 24 h upto $96 \mathrm{~h}$. Concentrations given are the final concentration (w/v) in the glass aquarium water. The t-ratio was $>1.96$, g-value $<0.5$ and heterogeneity factor $<1.0$ at all probability level (90, 95 and 99$)$ slope value is \pm SE of six replicates. Significant $(\mathrm{P}<0.05)$ negative regression was observed between exposure time and $\mathrm{LC}_{50}$ of treatments. Ts- testing significant of the regression coefficient- Ext Chl$-0.623^{+}$and $1025^{++}$in winter; $-5.792^{+}$and $1066^{++}$in summer. Pure Chl- $-0.954^{+}$ and $137.5^{++}$in winter; $-0.144^{++}$and $22.53^{++}$in summer.

+ : linear regression between $\mathrm{x}$ and $\mathrm{y} ;+++$ non linear regression between $\log \mathrm{x}$ and $\log y$.

Abbreviations: Chl, chlorophyllin; Pure Chl, pure chlorophyllin. LCL, lower confidence limit; UCL, upper confidence limit; 
Table 2: Toxicity of chlorophyllin in sunlight against Lymnaea acuminata

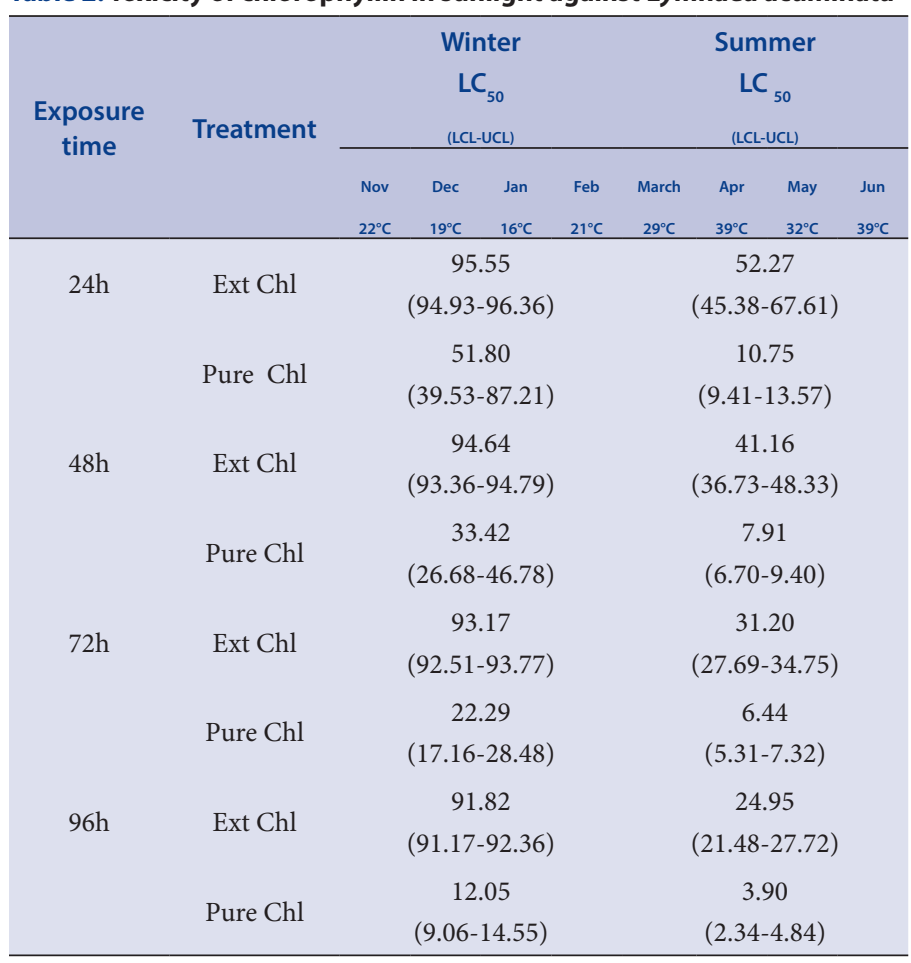

Each experiment was replicated six times. Toxicity measured at intervals of 24 $\mathrm{h}$ upto $96 \mathrm{~h}$. Concentrations given are the final concentration $(\mathrm{w} / \mathrm{v})$ in the glass aquarium water. The t-ratio was $>1.96$, g-value $<0.5$ and heterogeneity factor $<1.0$ at all probability level $(90,95$ and 99$)$ slope value is \pm SE of six replicates. Significant $(\mathrm{P}<0.05)$ was observed between exposure time and $\mathrm{LC}_{50}$ of treatments. Ts- testing significant of the regression coefficient- Ext Chl- $-0.064^{+}$and $102.1^{++}$in winter; $-0.522^{+}$and $101.7^{++}$in summer. Pure Chl- $-0.787^{+}$and $121.8^{++}$in winter; $-0.123^{+}$and $22.67^{++}$in summer.

+: linear regression between $\mathrm{x}$ and $\mathrm{y} ;++$ nonlinear regression between $\log \mathrm{x}$ and $\log y$.

Abbreviation: Chl, chlorophyllin; Pure Chl, pure chlorophyllin. LCL, lower confidence limit; UCL, upper confidence limit;

regression between exposure period and $\mathrm{LC}_{50}$ of chlorophyllin. Earlier, Wohllebe et al $^{18}$ have noted that chlorophyllin can kill the different stages of the protozoan parasite Ichthyophthirius mulftifiliis in fresh water fish species. It is reported that chlorophyllin was able to kill four different species, a small crustacean (Daphnia similis), a unicellular alga (Euglena gracilis) and two species of fish (Astyanax bimaculatus and Cyprynus carpio) the vector of parasitic diseases. ${ }^{19}$ Although it has been reported ${ }^{19}$ that chlorophyllin is toxic against Astyanax bimaculatus and Cyprynus carpio, yet in our observation it is not toxic against C. fasciatus. Both extracted and pure chlorophyllin are more effective in summer than winter. Water in winter season holds more oxygen ${ }^{20}$ Singh et al. ${ }^{21}$ reported that in 2010 summer water temperature was in between $20^{\circ} \mathrm{C}$ to $35^{\circ} \mathrm{C}$ in year 2010. The reported dissolved oxygen concentration in this water was 2.0 to $4.0 \mathrm{mg} \mathrm{L}^{-1}$, which caused higher mortality of snails. Earlier it was reported in my own laboratory ${ }^{22}$ that in warm water dissolved oxygen concentration in summer season is low $\left(2.0-4.0 \mathrm{mg} \mathrm{L}^{-1}\right)$ and in winter season it is high $\left(5.0-7.0 \mathrm{mg} \mathrm{L}^{-1}\right)$. In the present experiment when we have treated the same conditions while toxicity the chlorophyllin, it may be possible that their effect along with toxic singlet oxygen production in the body of the snail after the treatment of chlorophyllin enhances the snail mortality.
Whereas in winter, when water temperature and corresponding dissolved oxygen concentration was in between $18^{\circ} \mathrm{C}$ to $25^{\circ} \mathrm{C}$ and was 5.0 to $7.3 \mathrm{mg} \mathrm{L}^{-1}$, respectively ${ }^{21}$. Higher toxicity of chlorophyllin in sunlight in comparison to laboratory condition is due to the more production of toxic singlet oxygen. Photodynamic reactions of chlorophyllin lead to the formation of the highly reactive singlet oxygen, which can react with various biomolecules. ${ }^{23}$ The toxicity of pure chlorophyllin is much more than extracted chlorophyllin because it is isolated from extraction of spinach. And it has high concentration of chlorophyll in comparison to extracted chlorophyllin which consist other component such as carotene, xanthophylls, and many other components too. ${ }^{24}$ The HPLC (High performance liquid chromatography) was done in my own laboratory by Chaturvedi and Singh ${ }^{25}$ identification of active components in the extracted and pure chlorophyllin.

Chlorophyllin is a derivative of chlorophyll, ${ }^{26}$ in which magnesium atom at the centre of the ring is replaced with copper and phytol tail is lost. ${ }^{27}$ Due to loss of phytol ring chlorophyllin is more soluble and stable in water than chlorophyll. ${ }^{28}$ Chlorophyllin is accumulated in the intestine of exposed mosquito larvae and cercaria larva due to its higher solubility. ${ }^{29,7}$ Recently, Chaturvedi and Singh, ${ }^{30}$ also observed the toxicity of chlorophyllin against Lymnaea acuminata at different wavelengths of visible light. Photosensitization of this chlorophyllin produces reactive oxygen substances causing cell death. ${ }^{31}$ Very earlier, Singh et al..$^{32}$ was studied the larvicidal activity of photodynamic product pheophorbide a in different wavelength of light as well as in sunlight against cercaria larvae. The $96 \mathrm{~h}$ $\mathrm{LC}_{50}$ of toxicity of pure chlorophyllin $\left(3.90 \mathrm{mg} \mathrm{L}^{-1}\right)$ in sunlight is lower than active molluscicidal component Papain (9.74 $\left.\mathrm{mg} \mathrm{L}^{-1}\right)$, Quercetin (65.91 $\left.\mathrm{mg} \mathrm{L}^{-1}\right)$, thymol $\left(10.71 \mathrm{mg} \mathrm{L}^{-1}\right)$, and Citral $\left(16.68 \mathrm{mg} \mathrm{L}^{-1}\right)^{33-35}$ and synthetic molluscicides phorate $\left(15 \mathrm{mg} \mathrm{L}^{-1}\right)$, carbaryl $\left(14.4 \mathrm{mg} \mathrm{L}^{-1}\right)$ and formothion ( $\left.8.5 \mathrm{mg} \mathrm{L}^{-1}\right) \cdot{ }^{36}$ Extracted and pure chlorophyllin can be used as safe molluscicides as there was no mortality in fish even at $24 \mathrm{~h} \mathrm{LC}_{90}$ (against L. acuminata).

Evidence from the steep slope shows values indicate that a small increase in the concentration of the different treatments causes a marked mortality in snails. A t- ratio value greater than 1.96 indicates that the regression is significant. Values of heterogeneity factor less than 1.0 denote that in the replicate test of random samples, the concentration response lines would fall within $95 \%$ confidence limits, and thus the model fits the data adequately. The index of significance of potency estimation g-value indicates that the value of the mean is within the limits at all probability levels (90, 95 and 99) less than 0.5 .

\section{CONCLUSION}

It can be stated that water soluble chlorophyllin extracted from green plant leaves, can be used as potent molluscicides. Due to the photodynamic nature of chlorophyllin, it has the potential to control fasciolosis by killing the snails. Use of photodynamic chlorophyllin against snails, is one of the effective biotechnological tool for effective control of fasciolosis. The use of chlorophyllin is safe, as it is not toxic to fish sharing the same habitat.

\section{CONFLICT OF INTEREST}

We declare that we have no conflict of interest.

\section{ACKNOWELEGEMENT}

One of the authors Kavita Singh is thankful to Department of Science and Technology, (DST) New Delhi for financial assistance (Inspire Fellowship Number-IF 140959). 


\section{ABBREVIATIONS USED}

Chl: Chlorophyllin; Pure Chl: Pure chlorophyllin; LCL: Lower confidence limit; UCL: Upper confidence limit.

\section{REFERENCES}

1. WHO. Report of the WHO informal meeting on use of triclabendazole in fasciolosis control, 17-18 October. Geneva, Switzerland, WHO. 2006.

2. Mas-Coma S, Valero MA, Bargues MD. Fasciola, lymneids and human fasciolosis with a global overview on disease transmission, epidemiology evolutionary genetics, molecular epidemiology and control and other plant-borne trematode zoonoses. Adv Parasitol. 2009;69:41-6. https://doi.org/10.1016/S0065308X(09)69002-3.

3. Soni N, Singh DK, Singh VK. Inhibition kinetics of acetylcholinesterase and phosphatase by the active constituents of Terminalia arjuna and the Tamarindus indica in the cerebral ganglion of Lymnaea acuminata. Pharmacogn. J. 2017;9(1):98-101. https://doi.org/10.5530/pj.2017.2.25.

4. Mas-Coma S, Bargues MD, Valero MA. Fasciolosis and other Plant-borne trematode zoonoses Int J Parasitol. 2005;35(11):1255-78. https://doi.org/10.1016/j. ijpara.2005.07.010; PMid:16150452.

5. Salahi-Moghaddam A, Arfaa F. Epidemiology of human fascioliasis outbreaks in Iran J Arch Mil Med. 2013;1(1):6-12. https://doi.org/10.5812/jamm.13890.

6. Singh O, Agarwal RA. Toxicity of certain pesticides to two economic species of snail in northern India. J Econ Entomol. 1981;74(5):568-571. https://doi. org/10.1093/jee/74.5.568.

7. Singh DJ, Singh DK. Toxicity of chlorophyllin in different wavelength of visible light against Fasciola gigantica larva. J Photochem Photobiol, B: Biol. 2015;144:57-60. https://doi.org/10.1016/j.jphotobiol.2015.01.016 ; PMid:25720554.

8. Agarwal RA, Singh DK. Harmful gastropods and their control. Acta Hydrochim Hydrobiol. 1988;16(2):113-38. https://doi.org/10.1002/aheh.19880160202.

9. Singh DJ, Singh DK. Phytotherapy of chlorophyllin exposed Lymnaea acuminata: A new biotechnological tool for fasciolosis control. Parasite Epidemiol. Control. 2016;1(2):20-5. https://doi.org/10.1016/j.parepi.2016.03.005

10. Luna JS, Santos AF, Lima MRF, Omena MC, Mendona FAC, Bieber LW. A study of the larvicidal and molluscicidal activities of some medicinal plants from northeast Brazilian J Ethnopharmacol. 2005;97(2):199-206. https://doi.org/10.1016/j. jep.2004.10.004; PMid:15707752.

11. Singh A, Singh DK, Misra TN, Agarwal RA. Molluscicide of plant origin. Biol Agric Hortic. 1996;13(3):205-52. https://doi.org/10.1080/01448765.1996.9754782.

12. Tekwu EM, Bosompem KM, Anyan WK, Appiah-Opong R, Owusu KB, Tettey MD, et al. In Vitro Assessment of Anthelmintic Activities of Rauwolfia vomitoria (Apocynaceae) Stem Bark and Roots against Parasitic Stages of Schistosoma mansoni and Cytotoxic Study. J Parasitol Res. Volume 2017 (2017). Article ID 2583969, 11 pages. https://doi.org/10.1155/2017/2583969.

13. Erzinger GS, Hader DP. Bioinsecticide nontoxic biodegradable from UNIVILLE. 2009 National Institute of Intellectual Property - INPI. No.020090120220.20.

14. Wohllebe S, Ulbrich C, Grimm D, Pietsch J, Erzinger G, Richter R, et al. Photodynamic treatment of Chaoborus crystallinus larvae with chlorophyllin induces Necrosis and apoptosis. Photochem Photobiol. 2011;87:1113-22. https://doi. org/10.1111/j.1751-1097.2011.00958.x. PMid:21699544.

15. Singh DK, Agarwal RA. Correlation of the anticholinesterase and molluscicidal activity of the latex of Euphorbia royleana Bioss. on Lymnaea acuminata. J Nat Prod. 1984;47(4):702-5. https://doi.org/10.1021/np50034a023 ; PMid:6491683.

16. Robertson JL, Russell RM, Preisler HK, Savin NE. Bioassay with Arthropods. POLO computer programme for Analysis of Bioassay Data, second ed. CRC Press/Taylor and Francis. 2007;1-224.

17. Sokal RR, Rohlf FJ. Introduction to Biostatistics. W. H. Freeman and Co., San Francisco. 1995:271-3.

18. Wohllebe S, Richter P, Hader DP. Chlorophyllin for the control of Ichthyophthirius mulftifiliis (fouquet). Parasitol Res. 2012;111(2):729-33. https://doi.org/10.1007/ s00436-012-2893-y; PMid:22476598.

19. Erzinger GS, Souza SC, Pinto LH, Hoppe R, Del-Ciampo LF, Souza O, Correia CH, Hader DP. Assessment of the impact of chlorophyll derivatives to contro parasites in aquatic ecosystems. Ecotoxicol. 2015;24(4):949-58. https://doi. org/10.1007/s10646-015-1437-5; PMid:25750014.

20. Waterwatch Australia. National Technical Manual. Module 4 Physical and chemical Parameters. Waterwatch Australia Steering Committee Environment Australia (www. Waterwatch.org.au) 2002:ISBN 0642548560

21. Singh V, Singh VK, Singh DK. Seasonal variation in the toxicity of carbamyl to the snail Lymnaea acuminata: Implications for dosing regimens. Aus J Ecotoxicol. 2010;16:1-8.

22. Srivastava S, Tripathi AP, Singh VK, Singh DK. Environmental factors and the toxicity of Eugenol and Quercetin against snail Lymnaea acuminata. Res J Environ Toxicol. 2015;9(6):332-41. https://doi.org/10.3923/rjet.2015.332.341.

23. Spikes JD. Light in disease and therapy. Plenum Press, New York. 1979;5:251-60.

24. Anonymous. Report of the Second Working Group Meeting on the Markerels (Decapterus and Rastrelliger spp.) in the Malacca strait, 4-9 October 1985, Colombo, Sri Lanka, Bay of Bengal Programme Document. 1985;23p.

25. Chaturvedi, D. (2016). Molluscicidal activity of photodynamic products of chlorophyll against Lymnaea acuminata and Indoplanorbis exustus. Ph.D. Thesis. DDU Gorakhpur University, Gorakhpur.

26. Sarkar D, Sharma A, Talukder G. Chlorophyll and chlorophyllin as modifiers of genotoxic effects. Mutation Res. 1994;318:239-47. https://doi.org/10.1016/01651110(94)90017-5.

27. Berezin BD, Berezin MB, Moryganov AP, Rumyantseva SV, Dymnikova NS Chlorophyll and its derivatives, chlorins and porphyrins, as a promising class of environmentally friendly dyes. Russ J App Chem. 2003;76(12):1958-61. https:// doi.org/10.1023/B:RJAC.0000022447.81026.1a.

28. Sarkar D, Sharma A, Talukder G. Comparison of the effects of crude extract of spinach- beet leaves and equivalent amounts of chlorophyll and chlorophyllin in modifying the clastogenic activity of chromium (VI) oxide in mice in vivo. Phytother Res. 1995;9(3):199-202. https://doi.org/10.1002/ptr.2650090309.

29. Erzinger GS, Wohllebe S, Vollarth F, Costa SC, Ritcher P, Lebert M, et al. Optimiz ing condition for the use of chlorophyll derivatives for photodynamic control of parasites in aquatic ecosystems. Parasitol Res. 2011:109(3):781-6. https://doi. org/10.1007/s00436-011-2322-7; PMid:21448572.

30. Chaturvedi D, Singh VK. Toxicity of chlorophyllin against Lymnaea acuminata at different wavelengths of visible light. Trop. Life Sci. Res. 2016;27(2):25-36 https://doi.org/10.21315/tlsr2016.27.2.3 ; PMid:27688849 PMCid:PMC5031161.

31. Kohen R, Nyska A. Oxidation of biological system: oxidative stress phenomena antioxidants, redox reactions, and methods for their quantification. Toxicol Pathol. 2002;30(6):620-50. https://doi.org/10.1080/01926230290166724 PMid:12512863.

32. Singh DJ, Singh VK, Singh DK. Photomediated larvicidal activity of pheophor bide a against cercaria larvae of Fasciola gigantica. Scientifica. 2017:Volume 2017, Article ID 5219194, 7 pages, doi.org/10.1155/2017/5219194.

33. Singh S, Singh VK, Singh DK. Molluscicidal activity of some common spice plant. Biol Agric Hortic. 1997:14(3):237-49. https://doi.org/10.1080/01448765.1 997.9754813.

34. Jaiswal P, Singh VK, Singh DK. Enzyme inhibition by molluscicidal component of Areca catechu and Carica papaya in the nervous tissue of vector snail Lymnaea acuminata. Pesti Biochem Physiol. 2008;92(3):164-8. https://doi.org/10.1016/j. pestbp.2008.07.011.

35. Singh KL, Singh DK, Singh VK. Characterization of the molluscicidal activity of Bauhinia variegata and Mimusops elengi plant extracts against the Fasciola vector Lymnaea acuminata. Rev Inst Med Trop Sao Paulo. 2012:54(3):135-40. https://doi.org/10.1590/S0036-46652012000300004; PMid:22634884.

36. Singh DK, Agarwal RA. In vivo and in vitro studies on synergism with anticholinesterase pesticide in the snail Lymnaea acuminata. Arch Environ Contam Toxicol. 1983;19:313-9. 
GRAPHICAL ABSTRACT

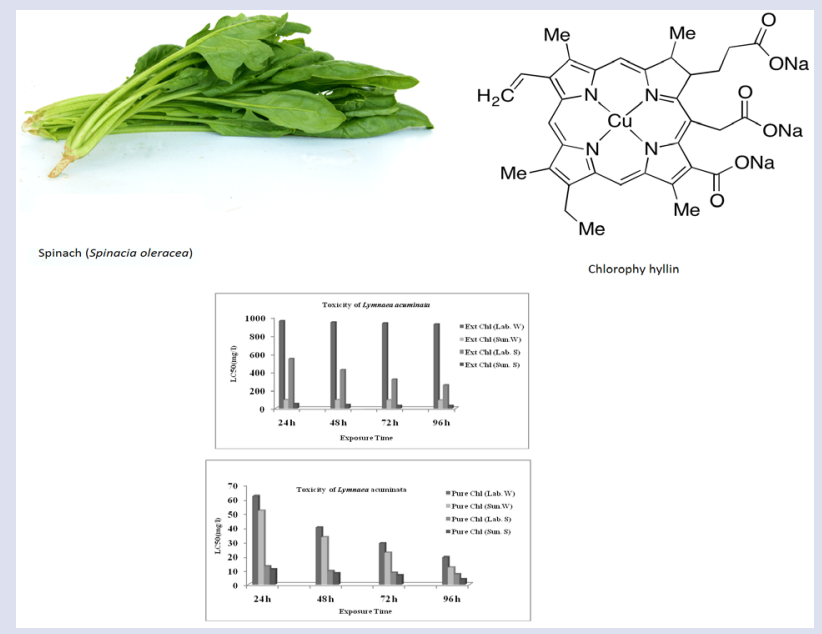

\section{HIGHLIGHTS OF PAPER}

- Water-borne disease fasciolosis also known as liver rot caused severe economic losses in Africa and Asia.

- The results of the experiment showed that the photodynamically active chlorophyllin, at low concentration was able to kill the snails under exposure of solar radiation in summer season instead of winter season.

- Pure chlorophyllin is more than five times toxic than synthetic molluscicides. It can be stated that water soluble chlorophyllin extracted from green plant leaves, can be used as potent molluscicides

- Phytotherapy of snails by photodynamic chlorophyllin is one of the effective biotechnological tool for effective control of fasciolosis

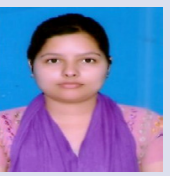

\section{AUTHOR PROFILE}

Kavita Singh: Research Scholar of Malacology Laboratory, Department of Zoology, DDU Gorakhpur University, Gorakhpur, UP, India. She completed her UG from St. Andrew's degree college and PG from DDU Gorakhpur University, Gorakhpur and enrolled for her doctorate studied under the supervision of Dr. Vinay Kumar Singh. She is gold medalist in M.Sc. Zoology from DDUGU in the year 2013 and also DST (Department of Science and Technology, New Delhi) INSPIRED FELLOW of 2014 (Inspire Fellowship Number-IF 140959). She has published 2 papers in an international journal and working on Effect of chlorophyllin/pheophorbide on the reproduction and development of snail Lymnaea acuminata.

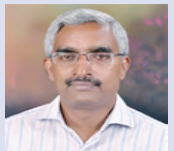

Professor D. K. Singh: Malacology Laboratory, Department of Zoology, DDU Gorakhpur University, Gorakhpur, UP, India has uni $\neg$ versity teaching and research experiences of more than 32 years. Current research interests are toxicology and molluscan physi-ology. He has published 182 research papers, 14 review articles in 75 leading International Journals of repute with high impact factors. Dr. Singh publications have got 3019 citations all over world having $28 \mathrm{H}$-index and $87 \mathrm{i}-10$ index Prof Singh has produced $26 \mathrm{Ph} . \mathrm{D}$. and successfully conducted 15 research projects.

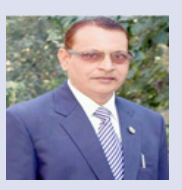

Dr. Vinay Kumar Singh: Assistant Professor stage-III, Department of Zoology, DDU Gorakhpur University, Gorakhpur, UP, India has university teaching and research experiences of more than 20 years. Current research interests are isolation, characterization and biological evaluation of natural products and pest control, vector-borne diseases. He has published 111 research papers, 10 review articles in 65 leading International Journals of repute with high impact factors. Dr. Singh has produced 11 Ph.D. and successfully conducted 01 research projects. Dr. Singh publications have got 799 citations all over world having $16 \mathrm{H}$-index and $23 \mathrm{i}-10 \mathrm{index}$. Dr Singh is serving as Editor-in-Chief of research J of Parasitology, USA. Dr. Singh was nominated as member of University Court (JNU) by Hon'ble President of India.

Cite this article : Singh K, Singh DK, Singh VK. Chlorophyllin treatment against the snail Lymnaea acuminata: a new tool in fasciolosis control. Pharmacog J. 2017;9(5):594-8. 